＜原 著 $>$

肝疾患患者における血中 Aldosterone の変動と Dopamine 調節

$\begin{array}{llllllr}\text { 村上 } & \text { 重人 } & \text { 大西 明弘 } & \text { 小坂 } & \text { 和宏 } & \text { 原田 } & \text { 誠 } \\ \text { 和田 } & \text { 光司 } & \text { 小田切理純 } & \text { 土屋 } & \text { 匠 } & \text { 大野 } & \text { 俊幸 } \\ \text { 小沢 } & \text { 靖 } & \text { 田中 照二* } & & & & \end{array}$

要 旨：肝障害の進展に伴い血中 catecholamine (CA) : norepinephrine(NE), dopamine(D) の上昇, renin-angiotensin-aldosterone (AD) 系元進が生ずる. D が AD 分必に対し負の調節 を行うと報告されている事から，我々はDの役割を調査するため，肝疾患患者 38 例，対照(C) 9 例に批いて D, CA， AD，腎機能 (CrCL) を比較検討し，次に肝硬変 (LC) 7 例，C 6 例に metoclopramide (MP) $20 \mathrm{mg}$ を投与し AD を経時的に測定，さらにD $3 \mu \mathrm{g} / \mathrm{kg} / \mathrm{min}$ 点滴下で 同様の操作を行った．同時に $\mathrm{Na}$ 利尿，prolactin(PRL) 分泌に対する Dの役割を Cと比較し た。 CA は肝障害に伴い上昇し $\mathrm{AD}$ と D は負の相関， D/NE 比と CrCLは有意な正の相関を示 した. MP 投与後の AD 反応は LCで大きく，逆に PRLはCが大きかった。また，D投与下で は PRL の反応は C， LC 共に抑制されたが，ADの反応はC 群で抑制傾向を示したものの LC 群では抑制されなかった。.以上より LCでは D/NE 比は腎機能のよい指標となり得 $\mathrm{AD}$ 分泌は PRL と異なりDのより強い緊張抑制下にある事が示された.

索引用語： 肝硬変 アルドステロンドパミン ノルェピネフリン プロラクチン

緒言

肝障害の進展に伴い腎よりの $\mathrm{Na}$ ，水の排泄能が低 下することが知られているが、これが肝硬变における 浮腫，腹水形成の一因ではないかと考えられている。 この肝障害に伴ら腎排泄能低下の原因の一つとして, renin-angiotensin-aldosterone（RAA）系の亢進 腎交感神経系活性化の関与が考えられて扣り，実際， 肝疾患患者の多くに高 aldosterone (AD) 血症, 血中 catecholamine (CA) 值の上昇が生ずることは従来よ ク多く報告されている11. 最近, Carey ら に dopamine (D) 受容体拮抗薬である metoclopramide (MP) 10mg を静注投与し，血中 AD 濃度が 著しく増加する事を報告したが，その後多くの研究に より，この反応が RAA 系, ACTH, 電解質 $(\mathrm{Na}, \mathrm{K})$ 等の $\mathrm{AD}$ 調節因子に無関保に起こることが確かめら れ $れ^{3.4)}$, 副腎皮質からの $\mathrm{AD}$ 放出に D 受容体が緊張抑制 の形で関与していること年多が明らかにされた。

$\mathrm{D}$ 自体は腎輸入血管を拡張し，堅血流量を増加させ，

- 東京慈恵会医科大学第三病院内科学第 1 講座 〈受付日1991年12月20日＞
系球体濾過率を増大させる，逆に，同じCAの一つで ある norepinephrine (NE) は腎輸入血管を収縮させ腎 血流量を減少させる，さらにNEは baroreceptorを 介し，あるいは直接旁系球体細胞の $\beta$ 細胞に働き， renin 放出，そして angiotensin(ANG) II の産生を促 し，二次的に副腎皮質からの AD 放出を刺激する。こ の様にNEと D は互いに拮抗した作用を有するため バランスをとりながら，腎血流量と AD の放出を調節 している可能性がある.肝硬変の進展に伴い AD が上 䄯したり腎機能が低下するのは，このバランスがくず れ，Dによる調節が効かなくなった事が一因になって いるのではなかららか，そこで我々はまず肝疾患患者 において血中 CA, $\mathrm{AD}$ を測定し，その相互関係及び腎 機能の指標としてクレフチニンクリフランス $(\mathrm{CrCL})$ を測定し，上記ホルモンとの関係を調査した。次に， $\mathrm{MP}$ を肝硬変患者に投与し，血中 $\mathrm{AD}$ 濃度を経時的に 測定し副腎皮質からの AD 放出に対する D受容体の 負の調節状態を健常人と比較し，さらに副腎と下垂体 の部位的違いはあるものの同しく D受容体によって 調節されている prolactin (PRL)を測定し，肝硬変に おけるD受容体を介する放出調節の違いを比較検討 
した.

\section{対象およひ方法}

Study 1 ；

肝矣患患者の血中 catecholamine 濃度

急性肝炎 $\mathrm{AH} ） 6$ 例, 慢性肝炎, $\mathrm{CH}) 8$ 例, 肝硬 变 LC) 24例: 代償性13例，非代償性11例)，健常人(C) 9 例の計4て例について血中 NE，D，血禁 renin 活性 PRA ), 及び血中 $\mathrm{AD}$ を早朝空腹時, 卧位 (30分間後) にて时静脈より採血し，0.1\%2NaEDTA を加之，遠 心分離後血漿をー $80^{\circ} \mathrm{C} て ゙$ 保存した後測定した。ささらに 肝㙨能の指標としてへパブラスチンテスト（HPT), ICG-15分值を，腎機能の指標として CrCLを测定し た. Table 1 に各群の年齢，体重，臨床検查値を示寸。 血中 CA の測定は既に報告済み”であるか，簡単に記 載すると。サンブルに1N 過塩素酸溶㾋を加えて除蛋

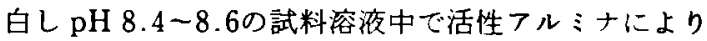
$\mathrm{CA}$ 含有成分を吸着させ，次に $0.4 \mathrm{~N}$ 酢酸水溶夜で $\mathrm{CA}$ を溶出し，HPLC.ECD 法で分析した。測定限界は各々 $20 \mathrm{pg} / \mathrm{m} l$ 以下，また測定日差，日内变動は6.5\%以内で
あった，PRA，ADはRIA 法(それぞれ固定法，2抗 体法）にて測定した。

\section{Study 2：}

肝硬変患者における metoclopramide 静注試领

上記 LC 患者の5ち 7 例（代償性 LC, 正常血圧）及 びCとして6 例 (Table 2)にMP (methoxy-2-chlolo5-procainamide，プリンベラン，藤沢薬品）を静注投 与し，血中 $\mathrm{AD}$ 及び PRL 濃度を投与前，投与後15分， 30 分，60分，120分，180分，に測定した，採血はすべ て留置翼状針 (时静脈) より行われ，すべて臥位にて 実施された。 また投与後180分間の蓄尿を行い $\mathrm{Na}$ 排泄 量を測定した. Study 2開始 1 週間前に, 180分間の蓄 尿を行い尿中 $\mathrm{Na}$ 排泄量を湘定し，対照として比較し た。上記 MP 投与は単盲検法にて 1 週間の wash out 時期をおき各例に 2 回実施され，そのうち 1 回は無作 為法で D (カコーシンン D 200, 日本製薬) $3 \mu \mathrm{g} / \mathrm{kg} / \mathrm{min}$ を MP 投与前後60分間投与し同様の操作を行った。な お，PRL の測定には RIA 法（2 抗体法）を用いた。

7 名の LC 患者は $120 \mathrm{mmol} /$ 日の $\mathrm{Na}$ 制限病院食を

Table 1 Patients characteristics in study 1.

\begin{tabular}{l|r|c|c|c|c|c}
\hline \multicolumn{1}{c|}{ subject } & No. & $\begin{array}{c}\text { Age } \\
\text { years old }\end{array}$ & $\begin{array}{c}\mathrm{BW} \\
\mathrm{kg}\end{array}$ & $\begin{array}{c}\mathrm{HPT} \\
\%\end{array}$ & $\begin{array}{c}\mathrm{ICG} \mathrm{R} 15 \\
\%\end{array}$ & $\begin{array}{c}\mathrm{CrCL} \\
\mathrm{m} l / \mathrm{min}\end{array}$ \\
\hline acute hepatitis & 6 & $34.2 \pm 5.3$ & $59.4 \pm 5.4$ & $82.8 \pm 1.8$ & $11.7 \pm 1.5$ & $91.5 \pm 8.5$ \\
chronic hepatitis & 8 & $45.1 \pm 5.7$ & $52.8 \pm 3.2$ & $87.0 \pm 1.6$ & $12.9 \pm 0.9$ & $65.6 \pm 7.2$ \\
liver cirrhosis & 24 & $58.4 \pm 1.6$ & $56.7 \pm 2.1$ & $59.4 \pm 3.6$ & $35.1 \pm 2.4$ & $62.0 \pm 3.5$ \\
control & 9 & $52.0 \pm 2.3$ & $63.0 \pm 3.7$ & & & $107.2 \pm 3.7$ \\
\hline
\end{tabular}

All data indicate mean \pm SEM. BW : body weight, HPT : hepaplastin test, ICG R15' : percent retention of indocyanine green at $15 \mathrm{~min}$ following the intravenous dose of 0.5 $\mathrm{mg} / \mathrm{kg}$ body weight. $\mathrm{CrCL}$ : creatinin clearance.

Table 2 Patient characteristics in study 2.

\begin{tabular}{c|c|c|c|c|c|c|c|c|c|c|c|c|c}
\hline patient & $\begin{array}{c}\text { Age } \\
\text { years old }\end{array}$ & $\begin{array}{c}\mathrm{BW} \\
\mathrm{kg}\end{array}$ & $\begin{array}{c}\mathrm{GOT} \\
\mathrm{IU} \text { L }\end{array}$ & $\begin{array}{c}\text { GPT } \\
\mathrm{IU} / \mathrm{L}\end{array}$ & $\begin{array}{c}\mathrm{T} \text {. Bil } \\
\mathrm{mg} / \mathrm{d} l\end{array}$ & $\begin{array}{c}\mathrm{Alb} \\
\mathrm{g} / \mathrm{d} l\end{array}$ & $\begin{array}{c}\mathrm{PT} \\
\%\end{array}$ & $\begin{array}{c}\mathrm{HPT} \\
\%\end{array}$ & $\begin{array}{c}\mathrm{ICG} \\
\mathrm{R} 15 \\
\%\end{array}$ & $\begin{array}{c}\mathrm{Na} \\
\mathrm{mEq} / \mathrm{L}\end{array}$ & $\begin{array}{c}\mathrm{K} \\
\mathrm{mEq} / \mathrm{L}\end{array}$ & $\begin{array}{c}\mathrm{CrCL} \\
\mathrm{m} l / \mathrm{min}\end{array}$ & etiology \\
\hline $\mathrm{KH}$ & 47 & 65.0 & 58 & 25 & 2.7 & 2.9 & 57 & 48 & 56.5 & 136 & 4.1 & 85.2 & alcoholic \\
$\mathrm{KH}$ & 63 & 36.0 & 20 & 8 & 1.4 & 3.5 & 76 & 63 & 17.7 & 143 & 2.4 & 46.1 & alcoholic \\
S S & 55 & 51.0 & 111 & 100 & 1.5 & 3.0 & 56 & 48 & 35.5 & 136 & 3.9 & 76.1 & posthepatitic \\
S H & 57 & 50.0 & 85 & 72 & 0.6 & 3.7 & 74 & 80 & 19.4 & 138 & 3.9 & 101.1 & alcoholic \\
K U & 52 & 76.0 & 157 & 83 & 1.2 & 3.3 & 66 & 93 & 31.0 & 137 & 3.7 & 47.5 & posthepatitic \\
H D & 58 & 55.0 & 72 & 51 & 1.5 & 3.0 & 65 & 60 & 44.8 & 142 & 3.9 & 76.3 & posthepatitic \\
E A & 65 & 49.2 & 42 & 17 & 0.9 & 3.1 & 75 & 95 & 33.0 & 139 & 3.9 & 41.9 & posthepatitic \\
Mean & 56.7 & 54.6 & 77.9 & 50.9 & 1.4 & 3.2 & 67.0 & 69.6 & 34.0 & 138.7 & 3.7 & 67.7 & \\
SEM & 2.3 & 4.8 & 17.2 & 13.4 & 0.3 & 0.1 & 3.2 & 7.5 & 5.2 & 1.1 & 0.2 & 8.6 & \\
\hline
\end{tabular}

BW : body weight, GOT : glutamate-oxaloacetate transaminase, GPT : glutamate-pyruvate transaminase, T. Bil : total bilirubin, Alb : albumin. PT : prothrombin time, HPT : hepaplastin test, ICG R15' : percent retention of indocyanin green at $15 \mathrm{~min}$ following the intravenous dose of $0.5 \mathrm{mg} / \mathrm{kg}$ body weight, $\mathrm{CrCL}$ : creatinin clealance 
少なくとも 1 週間前よりとっており，また study 前に ルーブ利尿薬( 2 日前), 抗フルドステロン性利尿薬( 1 週間前）の治療は使用されていれば中止とした。尚， 本研究は9：00AMから12：00AMに実施され，D投 与時は8：00AM より開始した。

\section{統計学的検討}

各数値は，平均値士標準誤差 (mean士SEM) で表現 し, student-t-testにより有意差検定を行い，必要時に は2-way ANOVA (Yukms 統計シリーズ)を用いて比
較し，危険率 (P) $5 \%$ 以下を有意差ありとした。 なた MP 投与後の反応を比較するために，投与前値 (B) と 投与後 1 時間までの最大値 ( $\mathrm{P})$ の比 $(\mathrm{P} / \mathrm{B})$ を求め, 投与後 1 時間までの各値から投与前値を引いた増加と 時間の曲線下面積である Area Under the Curve: $\Delta \mathrm{AUC}_{\mathbf{0}-1 \mathrm{nr}}$ を算出し使用した。

結果

Study : 1

各疾患別の NE, D, AD の值を Fig. 1 に示す. 血中
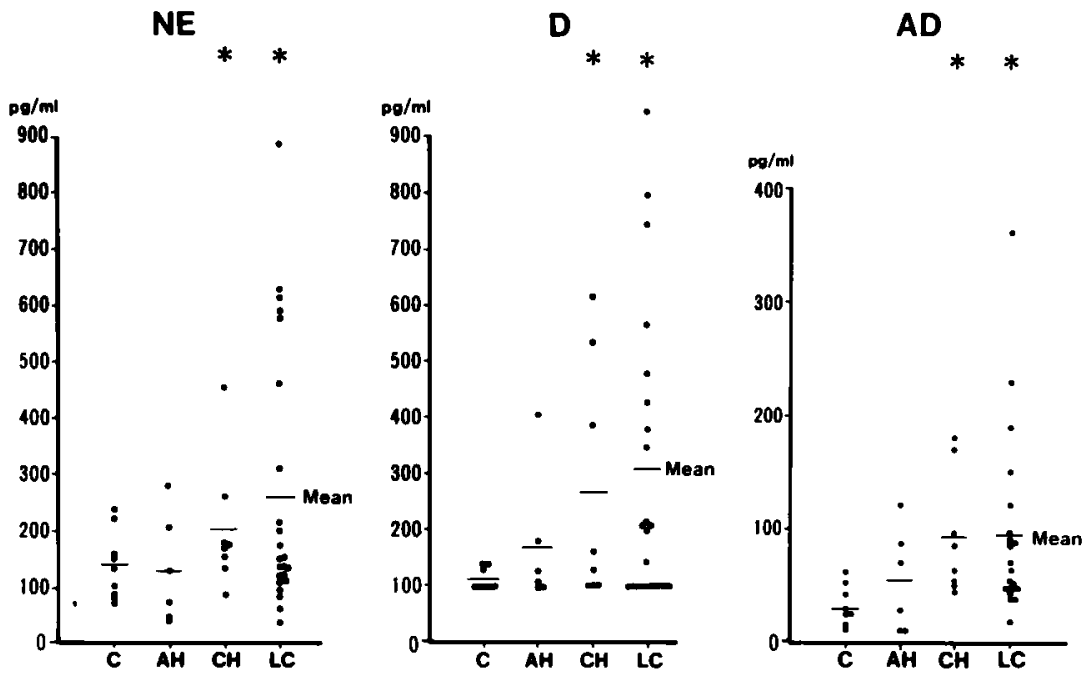

Fig. 1 Plasma norepinephrine (NE) (left), dopamine (D) (middle), and aldosterone (AD) (right) concentrations among three different liver diseases groups and control group. $\mathrm{AH}$ : acute hepatitis, $\mathrm{CH}$ : chronic hepatitis, $\mathrm{LC}$ : liver cirrhosis, $\mathrm{C}$ : control, * $\mathrm{p}<0.05$ compared to $\mathrm{C}, \mathrm{AH}$.

Table 3 Correlations among plasma aldosterone or $\mathrm{CrCL}$ and several parameters.

aldosterone correlation with

\begin{tabular}{|c|c|c|c|c|c|c|}
\hline & PRA & ICG R15 & HPT & $\mathrm{NE}$ & $\mathrm{D}$ & $\mathrm{D} / \mathrm{NE}$ \\
\hline $\mathbf{r}$ & 0.43 & 0.26 & -0.36 & 0.12 & -0.25 & -0.06 \\
\hline $\mathrm{p}$ & 0.01 & 0.07 & 0.02 & 0.25 & 0.07 & 0.38 \\
\hline \multicolumn{7}{|c|}{ CrCL correlation with } \\
\hline & PRA & ICG R15' & HPT & NE & $\mathrm{D}$ & $\mathrm{D} / \mathrm{NE}$ \\
\hline $\mathbf{r}$ & -0.45 & -0.17 & 0.20 & -0.34 & 0.25 & 0.64 \\
\hline p & 0.008 & 0.17 & 0.14 & 0.048 & 0.09 & 0.0004 \\
\hline
\end{tabular}

All correlations were obtained from 37 patients with liver diseases. PRA : plasma renin activity, ICG R15' : percent retention of indocyanine green at $15 \mathrm{~min}$ following the intravenous dose of $0.5 \mathrm{mg} / \mathrm{kg}$ body weight, HPT : hepaplastin test. NE : plasma norepinephrine concentration, $D$ : plasma dopamine concentration, NE/D: NE divided by $\mathrm{D}$ 
$\mathrm{CA}$ 値， $\mathrm{AD}$ 值ともに LC 群， $\mathrm{CH}$ 群， $\mathrm{AH}$ 群， C 群の 順に上昇しており， LC 群， CH 群は C 群， $\mathrm{AH}$ 群に比 しそれぞれ有意に $(\mathrm{p}<0.05)$ 高值を示した $(\mathrm{NE}, \mathrm{C}$ ： $141.1 \pm 17.6, \mathrm{AH}: 131.7 \pm 39.1, \mathrm{CH}: 202.9 \pm 39.8$, $\mathrm{LC}: 259.5 \pm 46.6 \mathrm{pg} / \mathrm{m} l, \mathrm{D}, \mathrm{C}: 111.1 \pm 5.0, \mathrm{AH}:$ $169.8 \pm 48.5, \mathrm{CH}: 265.6 \pm 75.6$, LC : $307.4 \pm 68.7$ $\mathrm{pg} / \mathrm{m} l, \mathrm{AD}, \mathrm{C}: 29.9 \pm 5.3, \mathrm{AH}: 54.2 \pm 18.4, \mathrm{CH}:$ $93.0 \pm 19.0, \quad$ LC : $94.1 \pm 16.4 \mathrm{pg} / \mathrm{ml})$.

Table 3 に示すごとく，AD 值と PRA 值は有意な 正の相関 $(\mathrm{p}<0.05)$ を示し，また $\mathrm{AD}$ 値は肝機能障害 の指標としての HPT, ICG と有意な負 $(\mathrm{p}<0.05)$ 及 び正の相関傾向 $(\mathrm{p}=0.07)$ を示した， $\mathrm{AD}$ 值と $\mathrm{D}$ 值は 負の相関傾向 $(\mathrm{p}=0.07)$ が認められた。 また， $\mathrm{CrCL}$ に対する CA の影響として, NE 值, D 值, D/NE 比に ついて調查した結果， $\mathrm{NE}$ 值と $\mathrm{CrCL}$ は有意な負の相 関 $(p<0.05)$ を，D值と CrCL は正の相関傾向を認め た（ $\mathrm{p}=0.09 ）$ 。さらに相反する働きを持つと考えられ る D と NEのバランスを表す D/NE 比と CrCLは有 意な正の相関関俰を示した $(p<0.001)$.

\section{Study ; 2}

MP 投与後の PRL, AD 值の推移を Fig. 2 に示す. PRL は LC 群, C 群とも投与後 180 分まで有意に $(\mathrm{p}<$ $0.05)$ 增加した。 $\mathrm{AD}$ 基礎値は $\mathrm{C}$ 群 $(33.9 \pm 4.9 \mathrm{pg} / \mathrm{ml})$
に比し LC 群 $(146.0 \pm 24.2)$ で有意に $(\mathrm{p}<0.01)$ 高値

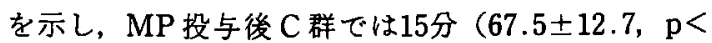
$0.05) ， 60$ 分 $(63.8 \pm 11.6, \mathrm{p}<0.05) ， 120$ 分 $(70.5 \pm$

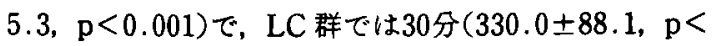

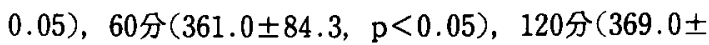

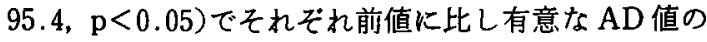
増加を認めた. Table 4 に示すごとく, AD と PRLの 反応を $\mathrm{P} / \mathrm{B}$ あるいは $\Delta \mathrm{AUC}_{0-\mathrm{n} \mathrm{n}}$ で比較したところ， MPに対する ADの反応は有意にLC群が大きく $\left(\triangle \mathrm{AUC}_{0-\mathrm{hr}}, \mathrm{C}: 25.9 \pm 9.2\right.$, LC : $167.1 \pm 54.6 \mathrm{pg} /$ $\mathrm{m} l \cdot \mathrm{h}, \mathrm{p}<0.05) ， \mathrm{PRL}$ の反応は有意にC 群の方が大

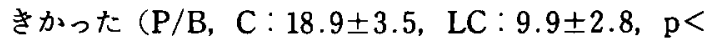
$0.05) . \mathrm{D}$ 投与下での $\mathrm{MP}$ 投与後の $\mathrm{PRL}, \mathrm{AD}$ 値の推移 を Fig. 3 に示す．D投与下では D 投与のない場合に 比し C 群での MP 投与に対する AD の反応は $\mathrm{P} / \mathrm{B}$, $\triangle \mathrm{AUC}_{0-1 \mathrm{~h}}$ ともに低下傾向を示した $(\mathrm{P} / \mathrm{B}, 2.3 \pm 0.5 \rightarrow$ $1.7 \pm 0.1, \Delta \mathrm{AUC}_{0-1 \mathrm{hr}}, 25.9 \pm 9.2 \rightarrow 18.8 \pm 3.1 \mathrm{pg} / \mathrm{m} l$. h)か，LC群では D 投与による差が認められなかった $\left(\mathrm{P} / \mathrm{B}, 3.0 \pm 0.6 \rightarrow 3.0 \pm 0.9, \Delta \mathrm{AUC}_{0-1 \mathrm{hr}}, 167.1 \pm 54.6\right.$ $\rightarrow 167.6 \pm 49.2 \mathrm{pg} / \mathrm{m} l \cdot \mathrm{h}) . P R L$ の反応は C 群, LC 群 ともD投与により有意に低下した（ $\triangle \mathrm{AUC}_{0-\mathrm{hr}}, \mathrm{C}$ ： $17.7 \pm 2.8 \rightarrow 10.1 \pm 1.5, \mathrm{p}<0.05, \quad$ LC $: 15.1 \pm 2.9 \rightarrow$ $9.0 \pm 2.4 \mathrm{pg} / \mathrm{m} l \cdot h, \mathrm{p}<0.05)$. また，MP 投与後 3 時
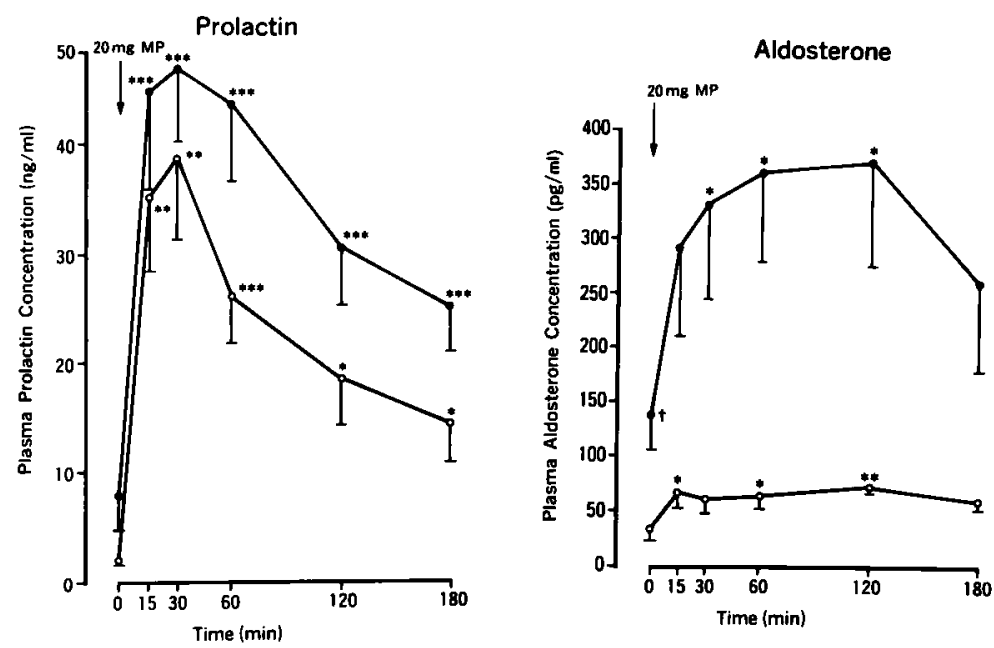

Fig. 2 Plasma prolactin (left) and aldosterone (right) responses to intravenous administration of metoclopramide $(20 \mathrm{mg}$ ) in 7 cirrhotic patients and 6 controls. Closed circle indicates the mean value of cirrhotic patients and open circle indicates the mean value of controls. MP : metoclopramide. ${ }^{*} p<0.05,{ }^{* *} p<0.01,{ }^{* *} p<0.001$ compared to baseline value, ${ }^{+} p<0.01$ compar. ed to baseline value of control. 
Table 4 Comparison of hormone responses to intravenous administration of metoclopramide with and without infusion of dopamine in patients with liver cirrhosis and in controls.

\begin{tabular}{r|c|c|c|c}
\hline & $\begin{array}{c}\text { baseline (B) } \\
\mathrm{pg} / \mathrm{m} l\end{array}$ & $\begin{array}{c}\text { peak value (P) } \\
\mathrm{pg} / \mathrm{m} l\end{array}$ & $\mathrm{P} / \mathrm{B}$ & $\begin{array}{c}\mathrm{AUC} 0.1 \mathrm{~h} \\
\mathrm{pg} / \mathrm{m} l \cdot \mathrm{hr}\end{array}$ \\
\hline $\begin{array}{r}\text { ALD response in C } \\
\text { without dopamine } \\
\text { with dopamine } \\
\text { in LC }\end{array}$ & $\begin{array}{r}33.9 \pm 4.9 \\
57.4 \pm 4.9\end{array}$ & $\begin{array}{l}73.4 \pm 10.6 \\
94.9 \pm 5.8\end{array}$ & $\begin{array}{l}2.3 \pm 0.5 \\
1.7 \pm 0.1\end{array}$ & $\begin{array}{c}25.9 \pm 9.2 \\
18.8 \pm 3.1\end{array}$ \\
$\begin{array}{r}\text { without dopamine } \\
\text { with dopamine }\end{array}$ & $146.0 \pm 24.2+$ & $401.0 \pm 75.6$ & $3.0 \pm 0.6$ & $167.1 \pm 54.6^{+}$ \\
& $188.0 \pm 42.8$ & $443.0 \pm 66.0$ & $3.0 \pm 0.9$ & $167.6 \pm 49.2$ \\
\hline \hline PRL response in C & $\mathrm{ng} / \mathrm{m} l$ & $\mathrm{ng} / \mathrm{ml}$ & & $\mathrm{ng} / \mathrm{m} l \cdot \mathrm{hr}$ \\
without dopamine & $2.2 \pm 0.3$ & $38.9 \pm 6.5$ & $18.9 \pm 3.5$ & $17.7 \pm 2.8$ \\
with dopamine & $1.1 \pm 0.1$ & $18.1 \pm 2.4$ & $16.8 \pm 2.6$ & $10.1 \pm 1.5^{*}$ \\
in LC & & & & \\
without dopamine & $7.9 \pm 2.8$ & $49.5 \pm 7.8$ & $9.9 \pm 2.8^{+}$ & $15.1 \pm 2.9$ \\
with dopamine & $4.3 \pm 1.1$ & $27.2 \pm 6.9$ & $8.2 \pm 2.1$ & $9.0 \pm 2.4^{*}$ \\
\hline
\end{tabular}

Dose of metoclopramide administered intravenously was $20 \mathrm{mg}$ and rate of infusion of dopamine was $3.0 \mu \mathrm{g} / \mathrm{ml} / \mathrm{min}$. ALD : aldosterone; PRL : prolactin; $\mathrm{C}$ : control subjects; LC : liver cirrhotic patients ; $P / B$ : peak value divided by basal value ; AUC $0.1 \mathrm{~h}$ : increase in area under the curve of plasma hormone-time relationship. All data present mean \pm SEM. " $p<0.05$ compared with the value without dopamine, $+p<0.05,+p<0.01$ compared with the value in control subjects without dopamine infusion.

\section{Aldosterone}

Prolactin

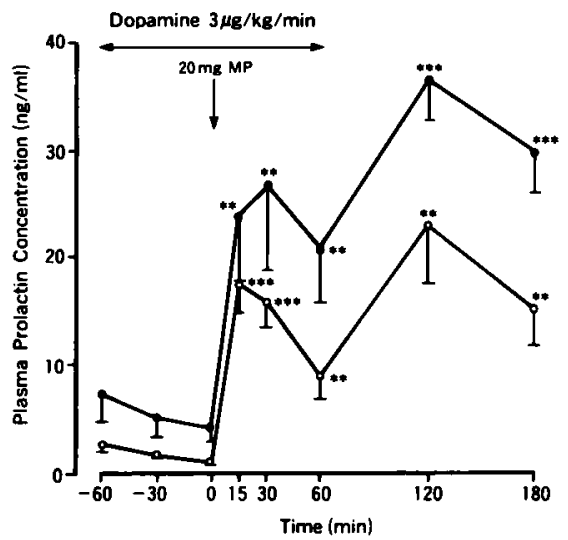

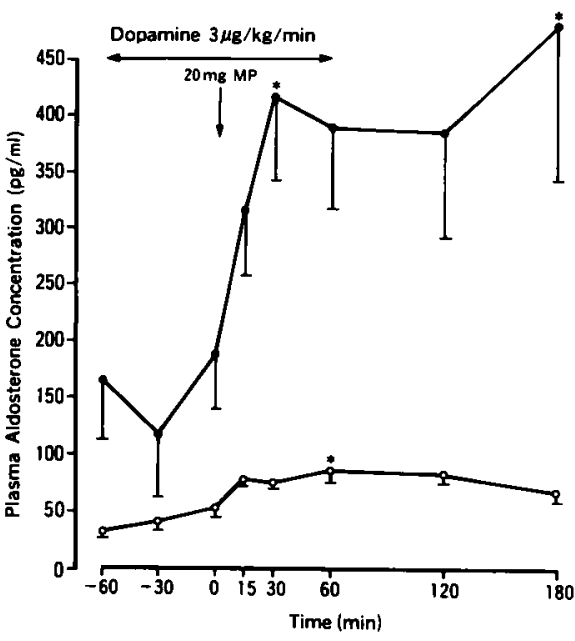

Fig. 3 Plasma prolactin (left) and aldosterone (right) responses to intravenous administration of metoclopramide $(20 \mathrm{mg}$ ) during and after intravenous infusion of dopamine $(3 \mu \mathrm{g} / \mathrm{kg} / \mathrm{min})$ in 7 cirrhotic patients and in 6 controls. Closed circle indicates the mean value of cirrhotic patients and open circle indicates the mean value of controls.

${ }^{*} \mathrm{p}<0.05, * * \mathrm{p}<0.01,{ }^{* * *} \mathrm{p}<0.001$ compared to baseline value. 
$14: 462$
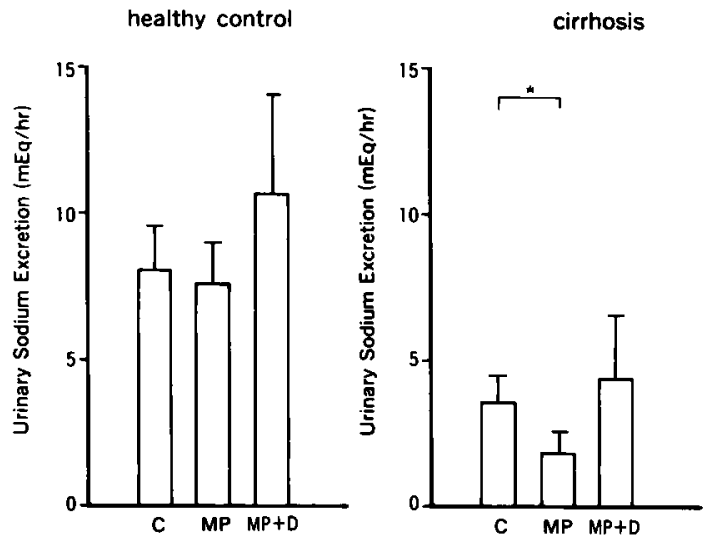

Fig. 4 Effect of intravenous administration of metoclopramide $(20 \mathrm{mg}$ ) on urinary sodium excretion with or without dopamine infusion at a dose of $3 \mu / \mathrm{kg} / \mathrm{min}$.

$\mathrm{C}$ : value in control period, MP : value after the intravenous administration of metoclopramide $(20 \mathrm{mg}), \mathrm{MP}+\mathrm{D}$ : value after intravenous admin. istration of metoclopramide $(20 \mathrm{mg})$ con comitantly with the infusion of dopamine at a dose of $3 \mu \mathrm{g} / \mathrm{kg} / \mathrm{min}$.

間の尿中 $\mathrm{Na}$ 排泄量を $\mathrm{LC}$ 群, C 群で比較すると C 群 $(8.0 \pm 1.5 \rightarrow 7.6 \pm 1.4 \mathrm{mEq} / \mathrm{hr})$ では MP 投与により $\mathrm{Na}$ 排泄量に差は認められなかったか，LC群（3.6士 $0.9 \rightarrow 1.82 \pm 0.7 \mathrm{mEq} / \mathrm{hr}, \mathrm{p}<0.05)$ では有意な $\mathrm{Na}$ 排 泄量の減少が認められた (Fig. 4)。をた，D投与時の $\mathrm{MP}$ 投与後 3 時間の尿 $\mathrm{Na}$ 排泄量は C 群, LC 群とも

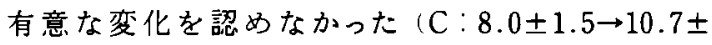
3.4 , LC : $3.6 \pm 0.9 \rightarrow 4.4 \pm 2.1 \mathrm{mEq} / \mathrm{hr})$.

\section{考 察}

進行した肝硬変患者における血中 CA 値の上昇は現 在に至るまで数多くの報告がある゙。このような肝硬 変患者では腎交感神経末端より NEが多く放出され， 腎旁米球体装置の $\beta$ 細胞を刺激し renin 放出が促進

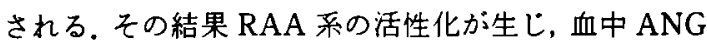
II が上昇し副腎から AD 放出が促される。卧において は血管収縮性ホルモンであるNEと ANGIIにより堅 の輸入血管収縮がおこり，Na 排泄量が低下しさらに $\mathrm{AD}$ 上昇により $\mathrm{Na}$ 貯留が促される．今回著者らは各 種肝疾患儿おいて対照群を含む計47例で血中 CA 値を 測定したが, 各種肝疾患における NE 值, AD 值は共に LC 群, CH 群で AH 群，C 群に比べ有意に高値を示 し，上記の順に增加傾向を示しており，多くの報告")と
33巻 6 号 (1992)

ほぼ一致していた。これらを各種肝機能検査の面から 検討すると, ICG, HPT 值と AD 值は有意な正及び負 の相関関係が得られ，肝機能の低下にともなって上昇 していると考えられた．肝障害進行にともなら（特に 肝硬变) 血中 $\mathrm{AD}$ 上昇の原因としては，有效循環血漿 量低下による RAA 系の活性化，低 $\mathrm{Na}, \mathrm{K}$ 血症等によ る $\mathrm{AD}$ 産生刺激，肝における $\mathrm{AD}$ 代謝の障害が考兵ら れるが、一方これらの分必刺激とは別に D 受容体によ る負の調節の存在も報告されている2 6). 本研究の study 1では, renin 値と $\mathrm{AD}$ 值の有意な正の相関が得 られ，一方で RAA 系の活性化に伴ら $\mathrm{AD}$ 値と D 值の 負の相関傾向が得られた。これは種々の肝疾患患者に おいて副腎からの AD 分必に対し負の D 調節機構が 存在する事を強く示㖫している。またこれまでいく つかの動物実験において副腎皮質球状層には，D受容 体が存在すると報告されており $\mathrm{AD}$ 分泌に D受容体 が関与していることが示唆されている89.9. そこで著者 らは LC 患者と健常人に D 受容体拮抗菜 ${ }^{10)}$ である MP $20 \mathrm{mg}$ を静注投与し，肝硬変患者における $\mathrm{D}$ の $\mathrm{AD}$ 調 節に対する作用を健常人と比較検討した。勿論 MP 自 体は ADの肝代謝に影響を及ぼさないことが報告さ れている(1). 本研究ではFig. 2に示すごとく，ADは MP 投与後，有意な増加を示した。これは MPによる $\mathrm{D}$ 受容体の拮抗作用によるものと考えられ従来の報告 と一致していた。この反応は LC 群で有意に大きく，さ らにこの反応が C 群で $\mathrm{D}$ 投与により抑制傾向を示し たが，LC群ではなんら抑制が認められなかった。この 副腎皮質からの MP 投与に上る $\mathrm{AD}$ 分泌反応が $\mathrm{LC}$ でなぜCに比べ大きいのか，どのような病態から生じ るのか,そして LCでDによる調節はどの様な形をと るのであろうか. LC では NE, ANG II の血中レベル の上昇による RAA 系の活性化や低 $\mathrm{Na} ， \mathrm{~K}$ 血症等で $\mathrm{AD}$ 分泌が常に刺激されている. study 1で見られるよ らにこの刺激に均衡をとるように，Dは LC 慢性肝 炎等の肝機能障害時において有意に上昇しており， 種々の AD 分泌刺激に相対している（抑制調節）と考 えられる，LCではDによるこの抑制調節が常に強く かかっているため, 一旦 MP 投与によってD受容体が 拮抗阻害され抑制が解除されると逆に強く $\mathrm{AD}$ の分 泌反応が生じると考えられる。また LCでは内因性 D による抑制刺激がいつも働いているため副腎の D受 容体は抢そらく感受性が低下していると考えられ，そ のため少量の外因性 D投与では，MP投与による $\mathrm{AD}$ 分泌反心は抑制できないと考えてよいのではなかろう 
か. また抑制刺激の形態は D投与下でMP 投与前の $\mathrm{AD}$ 值が有意な変化を示さなかった事から考えるとこ の調節機構はCarey らの提唱している緊張抑制の形 をとっていると考えてよいであろう。また D 投与によ り basal level はまったく抑制をらけなかったばかり かむしろ上昇傾向を示した。この上昇は扰そらく D投 与による血管払張が RAA 系の活性化を引き起こした ため，ANG II によるADの上昇が起きたのではなか ろうか。但し， ADを調節する他の因子，すなわち $\mathrm{ACTH}, \mathrm{K}, \mathrm{Na}$ ，心房性 $\mathrm{Na}$ 利尿ペプチド，RAA 系， 等は両群間で当然異なった状態であることが予想され るため、これらが同条件でない状態では推論の域を出 ない。

さて，我々は同じ D受容体により調節されている PRLについても比較した. PRLが $\mathrm{D}_{2}$ 受容体の調節を 受けていることはよく知られている．Fig. 2 に示すご とくPRL は MP 投与後有意な増加を示し，投与後 1 時間までの反応は $\mathrm{AD}$ とは逆にC 群の方が高値を示 寸傾向があり，P/B は LC 群に比し C 群で有意に高値 を示した(Table 4)。 また D 投与によって基礎值は抑 制傾向を示した。これは PRL 分必に対し D 受容体は, $\mathrm{AD}$ 分泌と同じ緊張抑制の形で抑制を行っているので はない事を示している。

さて同じDによって調節を受けていると考光られ る PRL，ADの反応が異なっているのはなぜだろう か. いくつかの理由が考えられるがまず第一に PRL 分泌抑制にかかわる受容体は $\mathrm{D}_{2}$ 受容体であるが, 副腎 での AD 分泌抑制に関してはいまだ明らかにされて いない。この受容体の相違が反応の差に現れている可 能性がある，第二に標的器官の違い（末梢と中权神経 系）がある. Fischerの仮説 ${ }^{21}$ に上れば肝性脳症の場 合，血中分岐鎖了ミ／酸の減少により血液脳関門で競 合する芳香族了ミノ酸の脳内侵入が高まる結果，Dな との正常な neurotransmitter の減少と, octopamine を中心とする偽性 neurotransmitter 物質の蓄積が脳 症を発現するとしている。本研究では肝性脳症の例は 無いが，対象とした全ての肝硬变患者は芳香族てミ， 酸の増加が予想されるため，健常人に比し視床下部で の D の減少により PRL 分泌抑制が低下している状態 と理解できる。そのため LC 群の方がMP投与後の PRL 増加率が低いと考えられる。三番目に LC 患者て は estrogen高值を呈することる知られており，

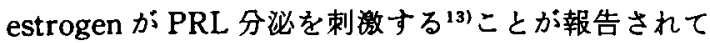
いることから，D 以外の調節物質の影響も考虑する必
要があると考えられる．以上のよ5にLC 患者におけ る AD 分必に関しては常にDの強い緊張抑制下にあ るが，PRLに関しては調節機構が緊張抑制でないこ と，受容体の差や部位的違い，あるいは病態に関連す る他の因子などによりこれら2つのホルモンの反応に 違いが生じたと考えられた。

次に LCで上昇しているDがどのよ5に腎機能及 び Na 利尿に働いているか study 1で検討してみた。さ きに述べたごとく肝障害の進展に伴い NE，Dは共に 上昇していた，NE上昇は，腎輸入血管を収縮し，腎血 流を低下させ，腎機能の低下につながる，本研究では $\mathrm{NE}$ と CrCLは有意な負の相関を認めており，これを 裏づけている，同時に，上昇した $\mathrm{D}$ 值は $\mathrm{CrCL}$ と正の 相関を示し，Dが腎機能に防御的調節機構として働く 可能性を示唆する結果となった。この関係(NE，Dの 相反調節)をさらに明確にするため, $\mathrm{D} / \mathrm{NE}$ 比と $\mathrm{CrCL}$ の関係を調查すると，高い正の相関関係が得られた。 このことは，肝硬变患者の腎機能が NEとDの均衡に よって調節されていることを示唆している。一般に, 腎での D 受容体は主に系球体と交感神経節後線維の シナプス前に存在し，NE放出を抑制する働きをるち， 腎内で放出された Dは，NEの米球体，尿細管に対す る働きを相殺する14)とされている。すなわち，NEは主 に輸出細動脈に働き，輸出細動脈を収縮させることに

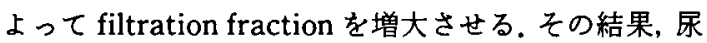
細管周囲の毛細血管の翏質浸透压が上昇し， $\mathrm{Na}$ 再吸 収が増大する。逆にDは輸出細動脈を拡張させ，逆の 作用により $\mathrm{Na}$ 再吸収が减少する14)。これらの意味で, 腎輸入動脈, 輸出動脈はともに D と NEの相反調節下 にあると考えてよいであろう．今回の著者らの研究で は，D，NEはともに上昇していたが，肝硬变患者に拉 いて，末梢静脈血中の $\mathrm{D} / \mathrm{NE}$ 比を評価してみると D/ $\mathrm{NE}$ と腎機能は高い相関関係が得られ，これか腎機能 のよい指標になりらるのではないかと考光られた。

そこでDの働きを阻害するMP投与がどの様に LC 患者でのNa 排泄に影響するかを調査したとこ ろ，MP 投与後 3 時間の尿中 $\mathrm{Na}$ 排泄量は，C 群に比 し，LC 群で有意に減少していた（Fig. 4)，Bernardi らの報告 ${ }^{15)}$ では，有腹水肝硬変患者において，MP 投与 後の尿中 $\mathrm{Na}$ 排泄率の减少を認めている. 彼らは，同時 に，MP 投与に上り采球体濾過率（GFR）が変化しな いことを確認し（GFR：95.8 $15.6 \rightarrow 100.9 \pm 9.9 \mathrm{ml}$ $\min , \mathrm{UNa}: 2.88 \pm 0.90 \rightarrow 2.16 \pm 0.66 \mathrm{mmol} / \mathrm{h}, \mathrm{n}=$ 13)，尿中 $\mathrm{Na}$ 排泄率之，血中 $\mathrm{AD}$ 值が，有意な負の相 
関関係を示すことを報告した。 また，尿中 $\mathrm{Na}$ と $\mathrm{K}$ の 比が有意に减少したことから，MP投与後の尿中 $\mathrm{Na}$ 排泄率低下の主因は $\mathrm{AD}$ 上昇によるものと結論つけ ている，以上の上らに，Dが肝硬变患者の腎機能，す なわち $\mathrm{CrCL} と \mathrm{AD}$ をへた $\mathrm{Na}$ 排泄能の両方に重要 な役割を担っていると考えることは妥当である5。一 方, 肝硬変患者に求こる $\mathrm{Na}$ 貯留, 堅血流の減少という 腎の機能的な異常に対して少量のD投与が試みられ てきたが，明らかな GFRや Na 排泄能の改善は認め られなかったとする報告がある ${ }^{16 \sim 18)}$. なた，選択的 $\mathrm{D}_{1}$ agonist である fenoldopamを用いた研究19)でも同様 に腎機能改善効果は得られていない, 我々のMP投与 前 1 時間の D 投与の結果からもわかるよ5に D 投与 によって $\mathrm{AD}$ 値は減少していない。これは， $\mathrm{AD} の \mathrm{D}$ による調節が，緊張抑制の形で存在するからであり， さきに述べた様に，ADの Dによる抑制が LC 患者で より強いと考えると，外部からの D投与に反応が鈍 く, 健常人の様に堅機能改善に向か5作用が得られな いと考えられるのではないか。

LC 患者における ADのDによる調節に関する報告 は少なく，未だ一定の見解は得られていない。しかし このことは, 肝硬变時の腎機能異常, ひいては機能的 腎不全といわれる肝腎症候群の原因となる数多くのメ カニズムの一つとして重要な意味を持つと考え報告し た.今後さらに詳細な研究を進め, 今回確認し得なかっ た腹水の有無での違い等今後の検討が必要と思われ た。また，制吐刜として広く使用されている MPを肝 硬変患者に投与する事は, $\mathrm{Na}$ 貯留傾向を助長し, 利尿 薬の効果を妨げる201恐れがあることも示唆された。

$$
\text { 文献 }
$$

1) Zambraski EJ, Dibona GF: Sympathetic nervous system in hepatic cirrhosis. "The Kidney in Liver Disease", 3rd ed, In: Epstein M, ed. Williams and Wilkins, New York, 1987

2) Carey RM, Thorner MO, Ortt EM : Dopaminergic inhibition of metoclopramide in. duced aldosterone secretion in man. J Clin Invest $66: 10-18,1980$

3) Sowers JR, Brickman AS, Sowers DK, et al: Dopaminergic modulation of aldosterone secetion by glucocorticoids and angiotensin block. ade. J Clin Endoclinol Metab 52 : 1078-1084, 1981

4) Dupont AG, Vanderneipen P, Smits JJ, et al:
Stimulation of aldosterone secretion by metoclopramide is not affected by chronic converting enzyme inhibition. Eur J Clin Pharmacol $29: 207-210,1985$

5) Noth RH, Mccallum RW, Contito $C$, et al: Tonic dopaminergic suppression of plasma aldosterone. J Clin Endoclinol Metab 51:64 $-69,1980$

6) Sommers DK, Meyer EC, Wyk M, et al: Aldosterone response to metoclopramide is mediated through the autonomic nervous system in man. Eur J Clin Pharmacol $33: 609-612$, 1988

7) Ohnishi A, Minegishi A, Sasaki $T$, et al: Effect of $\beta$-adrenoceptor blockade on exerciseinduced plasma catecholamine concentrations and their dissipation plofile. $\mathrm{Br} \mathrm{J}$ Clin Pharmacol 23 : 339-343, 1987

8) Dunn MG, Bossmann HB: Peripheral dopamine receptor identification: Properties of a specific dopamine receptor in the rat adrenal gromerulosa. Biochem Biophy Res Commun 99 : 1081-1087, 1981

9) Missale CM, Memo M, Liberini P, et al: Evidence for the presence of D1 and D2 dopamine receptors in the rat adrenal cortex. Eur J Pharmacol 109 : 315-316, 1985

10) Kebabian JW, Caline DB: Multiple receptors for dopamine. Nature 277 : 93-96, 1979

11) Brown $R D$, Wisgerhof $M$, Jiang $N$, et al: Effect of metoclopramide on the secretion and metabolism of aldosterone in man. J Clin Endoclinol Metab 52: 1014-1018, 1981

12) Fisher JE, Baldessarini RJ : False neurotransmitters and hepatic failure. Lancet $2: 75-79$, 1971

13) Monza GC, Lanpertico M, Ferrari A, et al: Prolactin and thyrotropin secretion in alcoholic liver cirrhosis: Study of the variations induced by TRH, Metoclopramide and cimetidine. J Nucl Med All Sci 25 : 71-78, 1981

14) Imbs JL, Schmidt M, Ehrhard D, et al: The sympathetic nervous system and renal sodium handling: Is dopamine involved? J Cardiovasc Pharmacol 6(Suppl 1) : 171-175, 1984

15) Bernardi M, Palma RD, Malatesta TR, et al : 
Unalterd dopaminergic modulation of aldosterone secretion in cirrhosis. Clin Sci $74: 137-142$, 1988

16) Barnardo DE, Baldus WP, Mahler FT : Effect of dopamine on renal function in patient with cirrhosis. Gastroenterology 58 : 524-531, 1970

17) Bennet WM, Keefe E, Melnyc C, et al : Responce to dopamine hydrochloride in the hepatorenal syndrome. Arch Intern Med 135: 964 $-971,1975$

18) Wilson JR: Dopamine in the hepatorenal syndrome. J Am Med Ass 238 : 2719-2720, 1977
19) Hadengue A, Moreau R, Bacq $Y$, et al : Selective dopamine DAl stimulation with fenol. dopam in cirrhotic patients with ascites: A systemic, splancnic and renal hemodynamic study. Hepatology $13: 111-116,1991$

20) D'Arienzo A, Amblogio G, Siervi PD, et al : A randamized comparison of metoclopramide and domperidone on plasma aldosterone concentration and on spironolactone-induced diuresis in ascitic cirrhotic patients. Hepatology 5: 854 $-857,1985$

\title{
Dopaminergic modulation of aldosterone secretion in cirrhosis
}

\author{
Shigeto Murakami, Akihiro Onishi, Kazuhiro Osaka, Makoto HaRada, Kouji Wada, \\ Toshizumi ODAgIRI, Takumi TsuchIYA Toshiyuki OHNo, \\ Yasushi OzAWA and Teruji TANAKA*
}

To investigate negative dopaminergic modulation to aldosterone secretion in cirrhotic patients having elavated plasma aldosterone $(\mathrm{AD})$ and catecholamine levels, we measured $\mathrm{AD}$, plasma norepinephrine (NE), dopamine (D), and creatinine clearance (CrCL) in 37 patients with hepatic diseases and 9 controls. Thereafter we compared plasma $\mathrm{AD}$ and prolactine (PRL) response induced by metoclopramide (MP, $20 \mathrm{mg}$ i.v.), a D receptor antagonist, between in 7 cirrhosis and in 6 controls. These hormones in plasma were elevated significantly $(p<0.05)$ in cirrhosis and chronic hepatitis patients compared with controls. Plasma $\mathrm{AD}$ was correlated negatively to $\mathrm{D}$ and $\mathrm{CrCL}$ was correlated positively $(p<0.001)$ to plasma $\mathrm{D} / \mathrm{NE}$ ratio. MP induced $\mathrm{AD}$ response was greater in cirrhosis than in control, whereas PRL response was greater in control. Although intravenous infusion of dopamine decreased PRL in both groups ( $p<0.05$ ), it did not produce any AD reduction in the basal and the MP induced response in cirrhosis but the small decrease in control. These results suggested that $D$ plays an important role for both renal function and $\mathrm{AD}$ secretion in cirrhosis. Tonic dopaminergic suppression to $A D$ appear to be enhanced in cirrhosis.

\footnotetext{
* Department of Internal Medicine (I), Daisan Hospital, The Jikei University School of Medicine (Tokyo)
} 